\title{
新潟県のハエについて
}

\section{Fly-fauna of medical importance in Niigata Prefecture}

\author{
齋 藤 豊* 大鶴 正 满** 須川 豊***
}

Yutaka Saito, Masamitsu Otsuru and Yutaka Sukawa

\section{緒言}

現今衛生害虫に関するる諸研究が各地で盛に行われるよ うになり, その分類, 分布, 季節消長並に疾病との関係 等に関する業績が頗る多くなつてきた。著者等もこれら の研究の一端として新潟県下の八エ相の調査に着手した が，今回は県衛生部の後援安得て1955年夏期孛中心に各 保健所別尼外及び室内の採集を行い，光の水平分布状 態を観察した外に，電源開発会社の後援も得て奥只見銀 山平，奥日光尾瀬及び北蒲原郡中条町櫛形山等の山地の ハェについても調查を䒠施した。総数戸外のハェ18,181 頭，室内の八エ 12,570 頭, 合計 30,751 頭について 分類し，10科 32 属 61 種に包含せしめたが，その八工相に 扮いて比較的興味深い点飞ついて以下要約的飞記述す

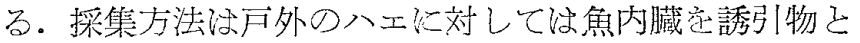

するケージトラップ，室内では八エトリリボンを用い， 更に山地に抬いては捕虫網学併用した。尚協力定仰いだ 保健所以村上, 新津, 津川, 巻, 三条, 与板, 長岡, 杤 尾, 小出, 六曰町, 十日町, 柏崎, 直江津, 高田, 相川 及び新潟の16カ所であつた。

\section{新潟県のハエの分類目錄}

新潟県平野部に所属する各保健所によつて夏季学中心 に採集された戸外の八恔数 15,308 頭で 9 科 27 属51 種, 室内の八エは 12,570 頭で 7 科14属24種に分類され そ. 同年 8 月10 11日の間に中条町櫛形山標高約 $450 \mathrm{~m}$ に掠いて採集した八エは1，486 頭で5科16属27種，奥只 見銀山平標高 550 800m飞抬ける同年 7月25～27日採 集したハエは 1,069 頭で 6 科20属32種, 更に県境群馬県

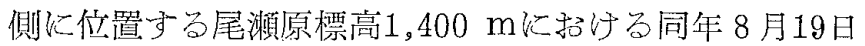

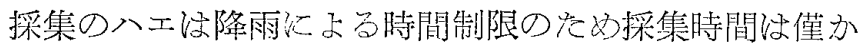

新潟県のハエの分類目録

\begin{tabular}{|c|c|c|c|c|c|c|c|}
\hline \multirow[b]{2}{*}{ 科 } & \multirow[b]{2}{*}{ 種 } & \multirow[b]{2}{*}{ 和 } & \multicolumn{2}{|c|}{ 採 } & 埸 & \multicolumn{2}{|c|}{ 所 } \\
\hline & & & $\begin{array}{l}\text { 装 } \\
\text { 野 } \\
\text { 部 }\end{array}$ & $\begin{array}{l}\text { 櫛 } \\
\text { 形 } \\
\text { 山! }\end{array}$ & $\begin{array}{l}\text { 銀 } \\
\text { 实 }\end{array}$ & $\begin{array}{l}\text { 尾 } \\
\text { 瀬 }\end{array}$ & 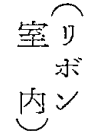 \\
\hline 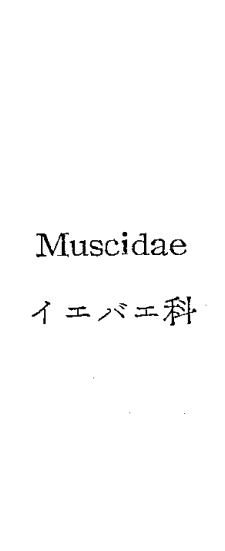 & $\begin{array}{l}\text { Musca domestica } \\
\text { Musca hervei } \\
\text { Musca convexifrons } \\
\text { Musca tempestiva } \\
\text { Muscina stabulans } \\
\text { Muscina angustifrons } \\
\text { Muscina assimilis } \\
\text { Muscina pabulorum } \\
\text { Graphomyia maculata } \\
\text { Morellia hortorum } \\
\text { Dasyphora cyanera }\end{array}$ & 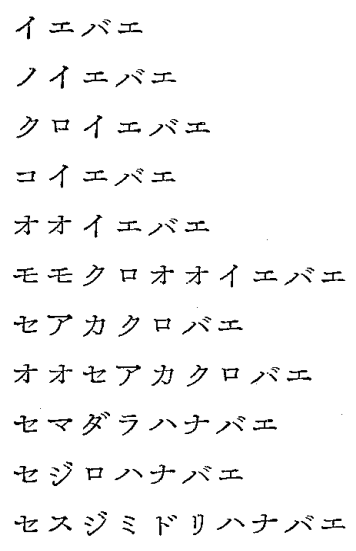 & $\begin{array}{r} \\
86 \\
423\end{array}$ & $\begin{array}{r}5 \\
41 \\
\\
3 \\
18 \\
51 \\
2 \\
\\
2 \\
3 \\
1\end{array}$ & $\begin{array}{l}3 \\
9 \\
2 \\
1 \\
5\end{array}$ & $\begin{array}{l}53 \\
27 \\
77\end{array}$ & $\begin{array}{r} \\
53 \\
282\end{array}$ \\
\hline $\begin{array}{l}\text { Stomoxyidae } \\
\text { サシバエ科 }\end{array}$ & $\begin{array}{l}\text { Stomoxys calcitrans } \\
\text { Stomoxys indica }\end{array}$ & $\begin{array}{l}\text { サシバェ } \\
\text { インドサシバェ }\end{array}$ & 2 & 7 & $\begin{array}{l}6 \\
1\end{array}$ & & 4 \\
\hline
\end{tabular}

* 新潟大学医学部細菌学教室

Dep. Bac., Niigata University School of Medicine

** 新潟大学医学部医動物学教宝
Dep. Med. Zool., Niigata University School of Medicine ****新潟県衞生部

Health Dep. in Niigata Prefecture 


\begin{tabular}{|c|c|c|c|c|c|c|c|}
\hline \multirow[b]{2}{*}{ 科 } & \multirow[b]{2}{*}{ 種 } & \multirow[b]{2}{*}{ 和 } & \multicolumn{3}{|c|}{ 採集 } & \multicolumn{2}{|c|}{ 所 } \\
\hline & & & $\begin{array}{l}\text { 平 } \\
\text { 野 } \\
\text { 部 }\end{array}$ & $\begin{array}{l}\text { 䈋 } \\
\text { 形 } \\
\text { 山 }\end{array}$ & $\begin{array}{l}\text { 銀 } \\
\text { 岸 }\end{array}$ & $\begin{array}{l}\text { 尾 } \\
\text { 瀬 }\end{array}$ & $\begin{array}{l}\text { 室 } \\
\text { ボ } \\
\text { 内式 }\end{array}$ \\
\hline $\begin{array}{c}\text { Anthomyiidae } \\
\text { ハナバエ科 }\end{array}$ & $\begin{array}{l}\text { Ophyra leucostoma } \\
\text { Ophyra chalcogaster } \\
\text { Ophyra nigra } \\
\text { Phaonia apicalis } \\
\text { Fannia canicularis } \\
\text { Fannia scalaris } \\
\text { Lispa sp. } \\
\text { Atherigona sp. } \\
\text { Limnophora } \mathrm{sp} . \\
\text { Anthomyia illocata } \\
\text { Hylemyia platura }\end{array}$ & $\begin{array}{l}\text { ヒメクロバエ } \\
\text { クロッヤハナバェ } \\
\text { ミヤマトゲハナバェ } \\
\text { ヒメイエバェ } \\
\text { コブアシヒメイエバエ } \\
\\
\text { クロオビハナバエ } \\
\text { タネバェ }\end{array}$ & $\begin{array}{r}212 \\
188 \\
12 \\
\\
73 \\
111 \\
\\
1 \\
3 \\
6 \\
31\end{array}$ & $\begin{array}{r}29 \\
5 \\
13\end{array}$ & $\begin{array}{r}64 \\
12 \\
16 \\
1 \\
1 \\
1 \\
16 \\
3 \\
\\
1\end{array}$ & $\begin{array}{l}1 \\
1\end{array}$ & $\begin{array}{r}22 \\
9 \\
31 \\
6056 \\
99\end{array}$ \\
\hline $\begin{array}{l}\text { Dolichopodidae } \\
\text { アシナガバエ科 }\end{array}$ & $\begin{array}{l}\text { Dolichopus sp. I } \\
\text { Dolichopus sp. II }\end{array}$ & & $\begin{array}{l}1 \\
1\end{array}$ & & & & $\begin{array}{l}1 \\
5\end{array}$ \\
\hline 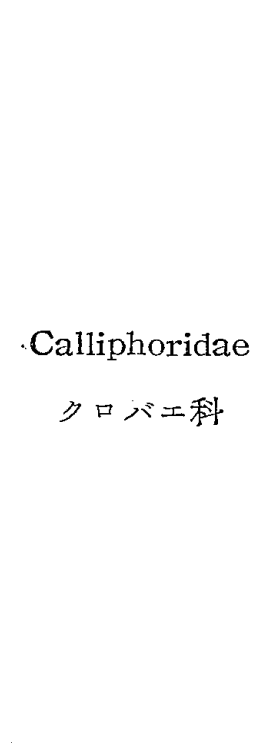 & $\begin{array}{l}\text { Calliphora lata } \\
\text { Aldrichina grahami } \\
\text { Triceratopyga calliphoroides } \\
\text { Lucilia caesar } \\
\text { Lucilia illustris } \\
\text { Lucilia ampullacea } \\
\text { Lucilia porphyrina } \\
\text { Lucilia papuensis } \\
\text { Hemipyrellia ligurriens } \\
\text { Phaenicia sericata } \\
\text { Phaenicia cuprina } \\
\text { Phormia regina } \\
\text { Protophormia terae-novae } \\
\text { Chrysomya pinguis } \\
\text { Stomorhina discolor }\end{array}$ & 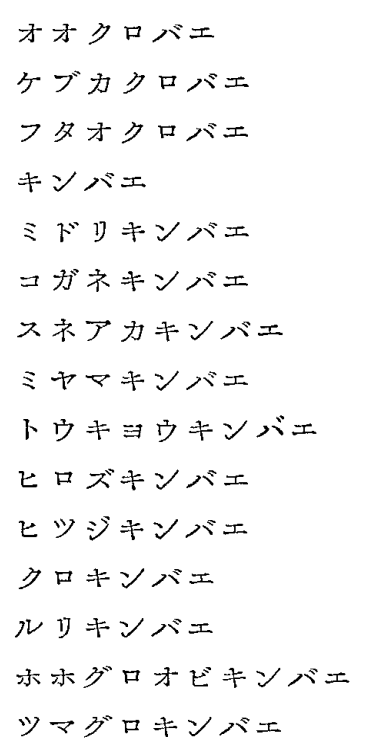 & $\begin{array}{r}186 \\
746 \\
43 \\
2181 \\
1772 \\
138 \\
73 \\
13 \\
174 \\
5799 \\
454 \\
5 \\
1 \\
117 \\
1\end{array}$ & $\begin{array}{r}20 \\
20 \\
132 \\
19 \\
\\
4 \\
1 \\
1 \\
\end{array}$ & $\begin{array}{r}66 \\
39 \\
105 \\
4 \\
4 \\
22 \\
54\end{array}$ & $\begin{array}{r}20 \\
209\end{array}$ & $\begin{array}{r}5 \\
20 \\
4 \\
7 \\
7 \\
3\end{array}$ \\
\hline 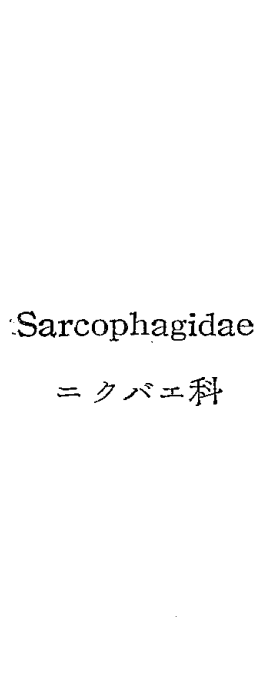 & $\begin{array}{l}\text { Sarcophaga peregrina } \\
\text { Sarcophaga similis } \\
\text { Sarcophaga septentrionalis } \\
\text { Sarcophaga albiceps } \\
\text { Sarcophaga melanura } \\
\text { Sarcophaga crassipalpis } \\
\text { Sarcophaga tsushimae } \\
\text { Sarcophaga polystylata } \\
\text { Sarcophaga harpax } \\
\text { Sarcophaga hori-kano } \\
\text { Sarcophaga misera } \\
\text { Sarcophaga schützei } \\
\text { Sarcophaga brevicornis } \\
\text { Blaesoxipha sp. }\end{array}$ & 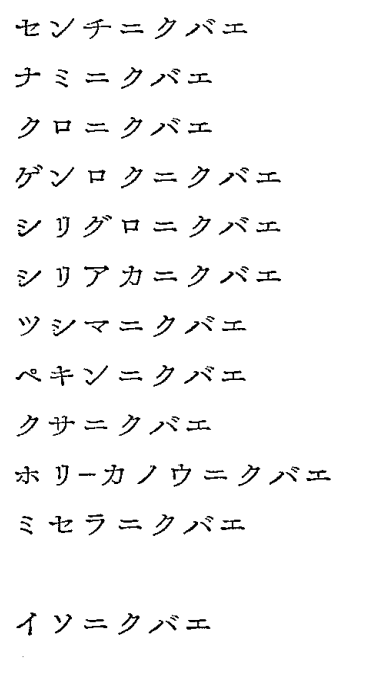 & $\begin{array}{r}1391 \\
247 \\
2 \\
50 \\
377 \\
5 \\
3 \\
44 \\
3 \\
1 \\
114 \\
2 \\
3 \\
2\end{array}$ & $\begin{array}{r}20 \\
6 \\
20 \\
2\end{array}$ & $\begin{array}{l}36 \\
38 \\
32 \\
32\end{array}$ & 4 & 38 \\
\hline
\end{tabular}




\begin{tabular}{|c|c|c|c|c|c|c|c|}
\hline \multirow[b]{2}{*}{ 科 } & \multirow[b]{2}{*}{ 種 } & \multirow[b]{2}{*}{ 和 } & \multicolumn{2}{|c|}{ 採 } & E 埸 & \multicolumn{2}{|c|}{ 所 } \\
\hline & & & $\begin{array}{l}\text { 平 } \\
\text { 野 } \\
\text { 部 }\end{array}$ & $\begin{array}{l}\text { 植 } \\
\text { 形 } \\
\text { 山 }\end{array}$ & $\begin{array}{l}\text { 銀 } \\
\text { 岸 }\end{array}$ & $\begin{array}{l}\text { 尾 } \\
\text { 瀬 }\end{array}$ & $\begin{array}{c}\text { 室 } \\
\text { 禾 } \\
\text { 内艺 }\end{array}$ \\
\hline $\begin{array}{l}\text { Helomyzidae } \\
\text { トゲハネバエ科 }\end{array}$ & Helomyza modesta & トゲハネバェ & 13 & & & & 50 \\
\hline $\begin{array}{c}\text { Scatophagidae } \\
\text { フンバェ科 }\end{array}$ & $\begin{array}{l}\text { Scopeuma stercorarium } \\
\text { Scopeuma mellipes }\end{array}$ & $\begin{array}{l}\text { ヒメフンバェ } \\
\text { キアシフンバェ }\end{array}$ & $\begin{array}{l}6 \\
2\end{array}$ & & & & \\
\hline $\begin{array}{l}\text { Dryomyzidae } \\
\text { ベッコウバェ科 }\end{array}$ & Stenodryomyza formosa & ベッコウバェ & 4 & & & & \\
\hline $\begin{array}{l}\text { Drosophilidae } \\
\text { ショウショウバェ科 }\end{array}$ & $\begin{array}{l}\text { Amiota variegata } \\
\text { Síegana sp. }\end{array}$ & マダラショウジョウバェ & & & $\begin{array}{l}1 \\
6\end{array}$ & 2 & \\
\hline
\end{tabular}

備考：表中の数字はハェ個体数

午後 1 時間であつたが 318 頭が捕獲され，乙れ尼 5 科 13 属18種に分類され\%。こ妃らの各採集場所別のハエの分 類目録岕別表の通りで，合計すると戸外及び室内の八エ の総捕獲数は 30,751 頭で10科32属 61 種が計上された。

\section{科别にみた各橿ハエの分布狀況}

\section{Muscidae $1 \mathrm{x} ヘ$ エ科について}

本科のむの性上記目録のように11種である。越後平野 部及び山脚地帯並に銀山平，尾瀬原及び櫛形山等の山地 に招いてとの科中共通的優越種で品つたのはMuscina 属の亡モク口オ才イエバェと才オイエバエの2 種で呫つ

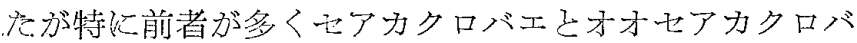
エとは山地で少数見出されたが平野部では採集されなか つた.Musca属ではイエバエがモモクロオオイェバェに 次いで各所以多く，ノイエバエはトラップでは殆ざ採れ なふつをが中条町石沢皮び櫛形山で家畜小屋及び牛体表 より捕虫網で採集容易であるとと学知る己共に，牛の眼 球附近にコイエバエが多いてと先人と均しく認めた. セマダラハナバエほ平野部でも山地でも普遍的に分布す るが個体数は極めて少く，せジハソバェ经面江津, 巻, 新潟市及び櫛形山等に执いて数個体見仙される稀薄種で セスシミミ゙リハナバェ经櫛形山で早 1 個体学トラップで 捕獲し得たの文であつた。リボンにる室内のイエバエ 科注大部分イエバェで，次で壬モク口才才イエバエ，他 飞少数のクロイエバエ，才オイエバェ及びノイエバエ 学多衣。

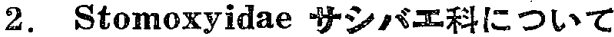

サシバエ驻普通のトラップで惊採集され難いがケージ 及びリボントラップ双方で数個体学捕蒦し，尚銀山平で 议捕虫網によりインドサシバェ今 1 頍学捕獲した。

\section{Anthomyiidae ハナバエ科について}

便宜上本科火11種学包含せしぬたが，その中で目下各 地方に普通に，しかも比較的濃厚に分布しているもの活 Ophyra 属亡 Fannia 属さで市り, 前属ではセメク口 バエを Ophyra chalcogaster こが多く，クロツヤハナ バエは県下一般に亘つて稀薄分布種であるが室内のリボ ンで採集率がよく，又山脚地帯及じ山地では比較的容易 《採集するととが出来た。 Fannia 属浪 2 種でヒメイエ バエが大多数で，コブアシヒメイエバエは比校的少丞か つた。 クロオビハナバェ，タネバェ及び Atherigona sp.

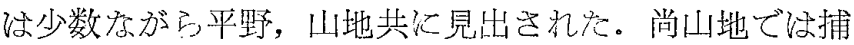
虫網飞より生態の明でないミヤマトグハナバエ，他に銀 山平の下水或住小川の水辺に Lispa sp. が多数多られ た. 又 Limnophora sp. が崇下一般に少数ながら分布し ていること辛認めた。

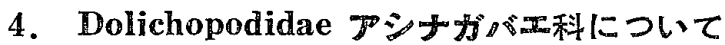

この科のハエ《新潟大学医学部では 5 月頃啳心桜の木 の下で焦団的に浮飛しているの完見か子るが生態が明で 京い，新潟紧下ではその 2 種孛区别出来，稀にケージ， リボントラップで捕獲出来たが地では見出されなかつ t.

\section{Calliphoridae 四任科について}

本科のハエは種類が多いとこ，及び各孚節を通じて優

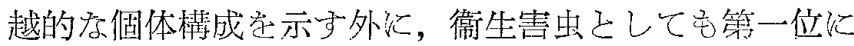
重要視せられているもので，県下ではその15種学譛め得 た. 平野部では Calliphorinii 中オオクロバェ及びケブ カクロバエが春秋奴山性に多数出現してくるが，フタオ クロバエねとの間に極く少数見出されるに過ぎないのは 日本内地共通の所見である.しかし夏の山では前二者が 盛に活躍しているの学久㐫。

地方別にキンバエ類の分布型式をみる己, 村上, 新潟, 
長岡，巻，与板地区ではヒロズキンバェ>ミドリキンバ エ>キンバェ, 柏崎, 直江津, 十日町地区でほヒロズキ ンバエ>キンバエ>ミドリキンバエ，佐渡相川ではヒロ ズキンバエ>キンバェ＞トウキョウキンバェ＞ミドリ キンバエ，新津ではヒロズキンバェ>キンバェ>ヒツ ジキンバェ>ミドリキンバェ，三条ではキンバエ>ヒロ ズキンバエ〉ミドリキンバエ，小出ではキンバエ〉ヒロ ズキンバエの分有順位学示し，とれらを新潟県全体上し てみるさ，ヒロズキンバエ>キンバエ>ミドリキンバエ ……分布状熊で汤つた。例外として三条のようにキ ンバエの優越した地区, 新津のよらにヒツジキンバェが 亦なり多い地方の西ると乞知り，面にコガネキンバェ 注春少数平地で見出され学が夏季怡殆ざ姿学かくし，ス ネアカキンバエ注新潟県では極めて稀薄な種類であるて とを知つ\%。しかし山間ではと机らの分布型式が全く趣 学異にし，ホホグロオビキンバエが第一位に優越し，七口 ズキンバエ致ざ文られずすしろキンバエが多くなり， ヌミヤマキンバエも普通種として見出すととが出来它.

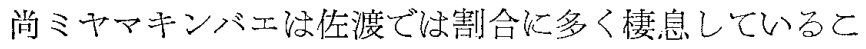

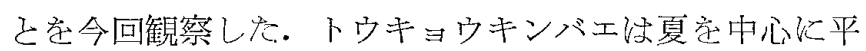
地では比較的容易に発見し得る種類であるが，銀山平及

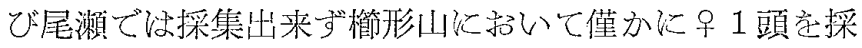

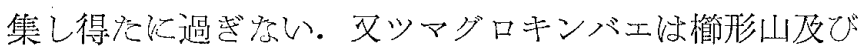
巻地区より少数見出し得をが他の地区から福証明击来な 加た。尚 7 月中旬直江津地区よりクロキンバエ合 5 頭, ルリキンバェ9 1 頭を見出し得をとさ结興味深い。リボ ンによるクロバエ科の八エ㤝，上記目録の如く7種で先

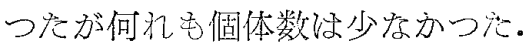

\section{Sarcophagidae $=$ ダエ科について}

県下のニクバェ科は平地及び山地を通じ14種で，その 中1種は新潟市よりのBlaesoxipha sp. であつた。本 利の分布状沉走久ると平野部の各地方に招いてセンチニ クバェ>シリグロニクバエ〉ナミニクバェ……其通 分布型式学見出星ととが出来\%。更飞地方別に見る己佐 渡亦らッシマニクバェ, 又日本海岸に沿つた近接地区か らはヘキンニクバェが見出され，大湯温泉（標高約 300

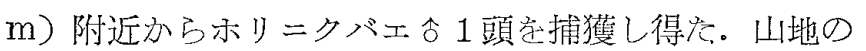
ニクバェ分布状況は平野部の乞机走趣它異にし銀山平で はナミニクバエ〉センテニクバェ＞ゲンロクニクバェ＞ シリグロニクバエ>クサニクバエ, 尾瀬ではナミニクバ エ>ゲンロクニクバエ, 櫛形山ではセンナニクバェ，ゲ ンロクニクバエ>ナミニクバェ>シリグロニクバェてい つた分布状態で，山地で汶一般にナミニクバエ，ゲンロ クニクバェが豊富になつて来るが種類訬少なかつた。

\section{Helomyzidae トゲハネバエ科について}

本科の1種トグハネバエば11月下旬〜12月初旬便所の
空ガラス, 魚屋及び一般戸外等に見かける不活澄なハェ であるが, 今回新津, 巻, 与板地区等から户外, 室内の 双方に見出さ机を。

\section{Scatophagidae フンバエ科について}

新鼬県下のフンバエは大部分ヒメフンバェでとれに極 く少数のキアシフンバエが共存するとと学佐渡及び巻の 採集標本から証明したが，そ记も早春及び晚秋认限つて w.

\section{Stenodryomyza formosa ベツコウバx}

晚秋少数ながら平野部の各地から採集された。

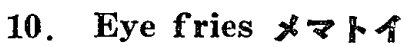

岡山地区よりメマトイさしてマダラショウジョウバエ が知られているが，銀山平及び群馬県の奥日光尾瀬地区 にはショウジョウバエ科のStegana sp. が濃厚化分布し 他にマダラショウジョウバェる確認した。

\section{総括}

1955年春〜冬の間新潟県下の八エ相の調查に当り協力

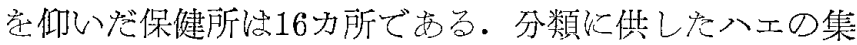
計は戸外のハエとして保健所採集の 15,308 頭に中条町 櫛形山，銀山平，尾瀬等で採集した山地の八エ2,873 頭 定加算して計 18,181 頭，室内のもの乞して保健所採集 の 12,570 頭，以上合計 30,751 頭で管つた。分類の結 果炡前記分類目録炕示したよう飞10科32属61種火わ炎つ た。しれらの八エ相定地方別に文ると，イエバエ科では モモクロオオイエバエが各地方定通じて優越種であり， ハナバエ科では Fannia, Ophyra 共以普遍的に分布して いるが，クロツヤハナバエは概して平野地带より山脚地 方に濃愿以分布しているるうである。次以重要なクロバ エ科の它の学通覽すると，キンバエ類でねヒロズキンバ 工第一位とず地方が大部分で，しかもセロズキンバ エ>ミドリキンバエ>キンバエ型分布が多く，次でヒロ ズキンバエ>キンバエ>ミドリキンバエ型の地区す焉つ た。異型のキンバエ>ヒロズキンバエ分布型に相当した

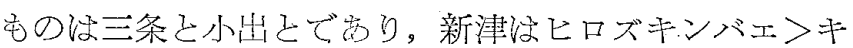
ンバエ>ヒツジキンバエ、ミドリキンバエ，佐渡相川は ヒロズキンバェ>キンバェ＞トウキョウキンバェ〉ミド

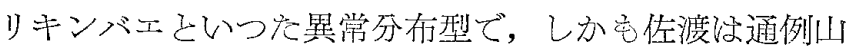
地でなければ見引れ㳊ミヤマチンバエが普通種さして楼 息していると己知つた。直江津地方加らクロキンバ エ，ルリキンバエが発見出来たのは将来小罗マヒ病毒等 の疫学調查堂行引場合何かの足埸になると思引。

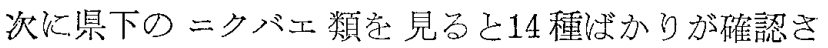
れ，乙名も各地方を通じ共通な分布型の存在寸ることを

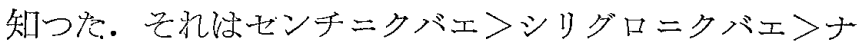
ミニクバエの分布型であるが，更に地方別にみるさ，佐 
渡ほ対島に招けよ弓にツシマニクバェ, 又日本海岸に沿 つた近接地区からは原記載が北京でるるぺキンニクバエ が見出されたこ己は興味深い、リボンによる室内のハエ 相はイエバェ>ヒメイエバエ分布型上その逆の個所があ り，乙れに他種少数の八エが加えられ，室内でも笑火多 数のハエ加侵入すること峜認めた。

次火季館消長について少しく触ててみる己，イエバェ 科, 八ナバエ科共に春, 夏, 秋に多く, クロバェ科で祦 Calliphoriniiの加く春々秋飞双山性活動定して夏季桨学 潜めるものとキンバェ類のうらにニクバエ科のハエ己共 に夏季学中心に活動しているもの>あるこしは一般と变 らない. フンバェ, ベッコウバェ惊早春, 晚秋飞活動性 であり，トゲハネバェは晚秋初冬に活動性である。

次に夏山のハェについて略述する己, 何処の山でも八 エは極めて多く不愉快であるが，その八工想你地区の それこかなり趣定翼にしている。即ち櫛形山，銀山平共 にホホグロオビキンバエが絶対多数定占わ，ヒロズキン バェは殆ご影定潜め, むしろキンバエが相対的に多く, ミヤマキンバェはその名にふさわしく山では普通種とし

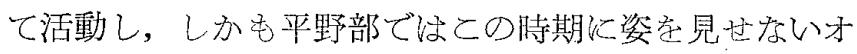
オクロバエ，ケブカクロバエが盛活躍している.

イエバェ科ではモモクロオオイエバエが山でも普通種 であり，又セアカクロバエ，才才セアカクロバエが容易 に見出される。八ナバエ科ではタロツヤハナバエが比較 的濃厚に分布し，又全国的心分布しているタネバェが山 地であ発罗された，フンバェ，ベッコウバェ等は採集さ れず、ニクバエ類では平野部の共通分有型であるセンチ ニクバエ>シリグロニクバエ>ナミニクバエが崩れ，櫛 形山ではセンチニクバェ>ゲンロクニクバエ>ナミニク バェ>シリグロニクバェ，銀山平ではナミニクバェ>セ ンテニクバエ>グンロクニクバエ〉シリグロニクバエ〉 クサニクバェ，尾瀬ではナミニクバェ>ダンロクニクバ エ上いつた分有状態で施つた。平野部に执ける上らに 多くの種類が見出されずナミニクバエ，ゲングロニクバ エ,シリグロニクバエがセンテニクバェさ后さ双肩的に 優占乞なつてくること定観察しね。

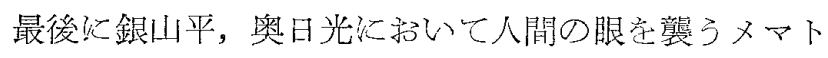
イの 2 種即与 Stegana sp. 及び Amiota variegata 乙文 発見出来たし己は興味深く, 労㗢又心眼疫の立場上から も看過出来ないものがある己考光。

稿を終るに臨み八エ同定上種々御教示を頂いた加納, 堀, 加藤三博士に深謝する。

\section{文 献}

1) 加納六郎 (1954)：日本のハ土, DDT 協会, 東京 -2) Kano, R. (1950-1955) : Notes on the flies of medical importance in Japan (Parts III, $V$ and IX) Bull. of Tokyo Med. and Dent. Univ. -3) Hori, K. (1950-1954) : Morphological studies on muscoid flies of medical importance in Japan (Parts III, V and VII) Sci. Rep. of Kanazawa Univ. and others. -4) 加藤静夫 (1951)：本邦に 於けるタマネギバェ (Hylemyia antiqua Meigen) の 買延と種類鑑別上の要点，防疫時舎，（22）：28～35. -5）菜木得一 (1954)：昆虫の分類, 北隆館, 東京。 -6) West, L. S. (1951) : The housefly. --7) Calyer \& Hammond (1951): Flies of the British Isles. -8) Dah1, F. (1928) : Die Tierwelt Deutschlands. -9)Loew (1858) : Wien. Ent. Mon. 2: 111 112. -10) Sabrosky, C. W. (1948): The muscoid genus Ophyra in the Pacific region (Diptera). Proc. Hawn. Ent. Soc., 13 ( 3 ): 423-432. -11) Graham-Smith, G. S. (1930): The Oscinidae (Diptera) as vectors of conjunctivitis, and the anatomy of their mouth parts. Parasitology $22(4): 457 \sim 467$. - 12) 駒草卓 (1952)：ショウ ジョウバェの遗伝と实駼 - -13) Graham-Smith, G. S.(1919): Further observations on the habits and parasites of common flies. Parasitology 11(3 8). 一14) 斎藤豊 (1955)：ハェについて(第 1 報)衞生新 潟, 1 (2): 12 14. -15) 斎藤豊, 大鶴正澫, 須 川豊 (1956): 新潟県の八土 (第 2 報) 衛生新潟, 2 (3) : $6 \sim 12$.

\section{Summary}

In 1955, with the assistance of 16 health centers in Niigata Prefecture, flies of medical importance were collected by means of a cage or ribbon trap throughout the year. They totalled 30,751 specimens consisting of 18,181 outdoor flies (15,308, collected in an open field, plus 2,873, trapped in such mountain areas as Kushigatayama, Ginzan-daira and Oze) and 12,570 indoor ones. As shown in the classification table, they were classified into 10 families, 32 genera and 61 species. To describe the fiy fauna, in family Muscidae, Muscina angustifrons held a superiority in every region. In family Anthomyiidae, both Fannia and Qphyra species were omnipresent, while Ophyra nigra was distributed more densely in a piedmont rather than in a plain.

In Greenbottle flies of family Calliphoridae, Phaenica sericata ranked first in inhabitation number in most of the regions.

A distribution of $P$. sericata $>$ Lucilia illustris $>$ L. caesar was observed in most of the region and that of $P$. sericata $>L$. caesar $>L$. illustris in some districts. An uncommon distribution of L. caesar $>P$. sericata was seen in Sanjo and Koide districts, that of $P$. sericata $>L$. caesar $>P$. cuprina. $L$. illustris in Niitsu district, and that of $P$. sericata $>$ L. caesar $>$ Hemipyrelia ligurriens $>$ L. illustris 
in Sado Island. And L. papuensis, which is usually seen in a mountain area only, inhabited as a common species in Sado Island.

Phormia regina and Protophormia terae-novae were found to inhibit in Naoetsu district. This may be of some help in the investigations of such an epidemic as polio.

Of Sarcophagid flies, 14 species were discovered in Niigata Prefecture and showed a distribution of Sarcophaga peregrina $>S$. melanura $>S$. similis common to every district. It was interesting that $S$. tsushimae was discovered in Sado Island as well as in Tsushima, and $S$. polystylata originally discovered in Peiping was found out in a coastal plain along the Japan Sea.

Concerning the fauna of indoor flies trapped by a ribbon, a distribution of $M u s c a$ domestica> Fannia canicularis type was seen in some districts and that of the reverse type in others. Other species of flies were also found in small numbers. It, therefore, followed that many species of flies would invade indoors.

Generally most of the flies of medical importance made three appearance in large numbers in spring, summer and autumn. Some species of family Calliphoridae, for instance, Calliphorinii, made their appearance in spring and autumn, and hid themselves in summer while Lucilia species are very common chiefly in summer, as flies of Sarcophagid flies did. Scopeuma stercorarium and Stenodryomyza formosa appears in early spring and late autumn, while Helomyza modesta in late autumn and early winter.

Any summer mountains abunded with flies, but a fly fauna in them was fairly different from that in a plain. To enter into details, in both
Kushigata-yama and Ginzan-daira, Chrysomya pinguis predominated in numbers; $P$. sericata hardly made its appearance; $L$. caesar was relatively numerous; $L$. papuensis was active as a common species in a mountain as its name suggests, and Calliphora lata and Aldrichina grahami, which, in a plain, do not usually make their appearance during summer, led an active life. Of family Muscidae, Muscina angustifrons was seen most frequently as a common species in a mountain region, and also $M$. assimilis and $M$. pabulorum were found easily.

Of family Anthomyiidae, Ophyra nigra was distributed comparatively densely, and Hylemyia platura, which is distributed all over the country, was also discovered in the mountain areas. Scopeuma stercorarium and Stenodryomyza formosa were not trapped in those places. As for Sarcophagid flies, a distribution of $S$. peregrina $>S$. melanura $>S$. similis commonly observable in a plain, did not stand for the mountain areas, that is, a distribution of $S$. peregrina $>S$. albiceps $>S$. similis $>S$. melanura was seen in Kushigata-yama, that of $S$. similis $>S$.peregrina $>S$. albiceps $>S$. melanura $>S$. harpax in Ginzan-doira, and that of $S$. similis $>S$. albiceps in Oze. In these districts, so many species of flies as those in the plains were not discovered, and $S$. similis, $S$. albiceps and $S$. melanura each made their appearances in nearly the same number as that of S. peregrina.

It was worthy of notice that two kinds of eye-flies, i.e., Stegana sp. and Amiota variegata, were discovered in Ginzan-daira and Oku-Nikko. We not pass this fact unnoticed from the standpoints of labour and prevention of an Eye-Disease.

\section{表 紙 写 負 說 明}

米ごころ越後方面で，田蜂，ミナクチムシ，アラマ ル，タムカデなざさいわれている水目の泥中棲息する

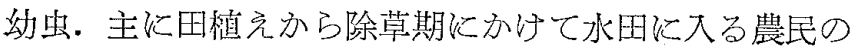

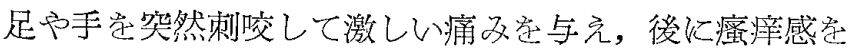
伴了皮膚症字残すので非常に嫌がられている。全てアブ 科 Tabanidae の幼虫で, 長さ $2 \sim 3 \mathrm{~cm}$ 紡鍾形, 刺咬 以出入自在の䫓部に方る強靶な管牙状の 1 対の大影飞よ

\section{るものである、数種あるようで，写真は向つて右より Tabanus trigonus ウシアブ Tabanus madarinus シロフアブ Tabanus takasagoensis ギシロフアブ} 任の3 個体注未決定。

(新潟大学医学部医動物学教室 大鶴正满傅士提供) 